\title{
Case of elderly abuse and violence against women: nose amputation
}

\section{Yaşlı İstismarı ve Kadına Şiddet Olgusu: Burun Amputasyonu}

\author{
Ilhan Halil Aydogdu ${ }^{1}$, Guven Seckin Kirci ${ }^{1}$, Hasan Okumus ${ }^{1}$, Mehmet Askay ${ }^{1}$, Erdal Ozer ${ }^{1}$, Ismail Birincioglu ${ }^{1}$
}

${ }^{1}$ Karadeniz Technical University, Faculty of Medicine, Department of Forensic Medicine, Trabzon/Turkey.

\section{Öz}

Burun, solunum ve koku organı olmasının yanı sıra anatomik olarak yüzün orta hattında önemli bir estetik unsurdur ve travmalara açık bir organdır. Bu nedenle özellikle şiddet olaylarında burun yaralanmaları ile sık karşılaşmaktayız. Aile içi şiddeti, kadına şiddeti ve yaşı istismarını nadir görülen bir olgu üzerinden tartışarak, ileri yaş grubunda da şiddetin değişik boyutlarda karşımıza çıkabileceğini hatırlatmayı amaçladık. Şiddet eylemleri içerisinde anatomik yapısı itibariyle çıııntıı organlara ya da estetik organlara saldırı eğilimleri de mevcuttur. Tarihte zina ve hırsızık suçunun cezası olarak nazal piramidin ampütasyonu eski uygarlıklarda hukuki bir yaptırım olarak karşımıza çıkmaktadır. Yüzün önemli bir estetik unsuru olan burnun, kıskançlık ya da intikam alma amacıyla da bilinçli olarak saldırıya uğraması mümkündür. Olgumuzda olduğu gibi yaşlı istismarının ve kadına şiddetin bir türü olarak karşımıza çıkabilmektedir. Dünya Sağlık Örgütü Toronto Deklarasyonu'na göre yaşlı istismarı: "güven beklentisi olan herhangi bir ilişkide, yaşlıya zarar veren veya onu strese sokan bir defa ya da tekrarlayan uygunsuz davranışlarda bulunulması"dır. Günümüz tıbbi imkanlarında her ne kadar başarılı burun replantasyon ve rekonstrüksiyon uygulamaları yapılabiliyor olsa da maruz kalınan ruhsal travmanın izlerinin silinmesi hiç de kolay değildir. Bu sebeple tüm yaş gruplarında, şiddet ve istismarı önlemede yasal düzenlemeler yapılmalı, eğitici programlar ve sivil toplum faaliyetleri planlanarak farkındalık yaratılması amaçlanmalıdır. Tüm koruyucu önlemlere rağmen meydana gelmiş istismar olgularında erken dönemde olgunun tıbbi ve sosyal destek sağlanması, ilerleyen dönemde takiplerinin yapılması ikincil ve üçüncül koruma kapsamında oldukça önemlidir.

Anahtar Kelimeler: Yaşlı İstismarı, Şiddet, Travma, Amputasyon, Burun

\section{ABSTRACT}

Nose is an organ for breathing and smelling and an important aesthetic factor in the middle of the face and it is vulnerable to traumas. Thus, we encounter nosebleeds frequently particularly in violence cases. We aim to remember that violence can come across clinicians in different formats in elderly patients by discussing domestic violence, violence to women and elderly abuse on a rare case. In act of violence, there is also a tendency of attacking aesthetic organs and protruding organs due to their anatomic forms. We encounter the amputation of nasal pyramid in history as a punishment of adultery and thievery in ancient civilizations as law enforcements. Nose as an important aesthetic factor of face, is possible to be attacked on purpose in order to take revenge or is jealousy cases. Similar to our case, we might encounter it as a type of elderly abuse and violence against women. According to World Health Organization Toronto Declaration, elderly abuse is: "acts of one or multiple inconvenient behaviors that harm the elders or distress them in a relationship with expectations of trust" Although nose replantation and reconstruction can be performed successfully with modern medical possibilities, erasing the marks of mental trauma is not easy at all. Therefore, in all age groups, legal acts must be done, educational programs and social society activities must be planned and creating awareness must be aimed in order to prevent violence and abuse. In abuse cases despite all protective measures, as a part of secondary and tertiary protection, it is significant to provide social and medical support and fallow-up in oncoming periods.

Keywords: elderly abuse, violence, trauma, amputation, nose

Corresponding Author: Dr. İlhan Halil Aydoğdu

Address: Karadeniz Technical University, Faculty of Medicine,

Department of Forensic Medicine, Trabzon/Turkey.

Başvuru Tarihi/Received: 21-05-2016

E-mail: ilhanaydogdu@gmail.com

Kabul Tarihi/Accepted: 04-05-2017 


\section{Introduction}

Violence, except defence and counter claim, described in dictionary as "vulgar power"; is considering the presence of others as a threat in order to provide dominance and a phsychological pattern of behavior intended to harm others and it can be seen in people and wild animals (1).

Nose is an organ for breathing and smelling and an important aesthetic factor in the middle of the face. In its structure, muscle and skin is on bone and cartilage. When we examine its anatomy; nasal root, nasal wing and nasal apex forms the external nose. Vascularization of this area is provided by subsections of a.facialis, a.labialis superior, a. ophtalmica and a.maxillaris. nasal cavity (cavitas nasale) is split in half by septum nasi and it opens to nasopharynx in the back. Nose is split in three functionally. Vestibulum nasi is the slightly wide part of the nasal cavity and hair named vibrissae can be found here in order to prevent the passing of foreign bodies to the respiratory tract. The area named regio respiratoria is the vascular rich area behind vestibulum and it is related to respiration. In regio olfactoria, scent cells and their extension exist $(2,3)$. Nose is vulnerably to trauma as a very important aesthetic component. Therefore, we encounter nose injuries frequently particularly in violence cases.

Old age; is a process that has unstoppable biological, chronological and social sides. Individuals usually lost their social standings in old age and become more dependent (4). According to World Health Organization Toronto Declaration, elderly abuse is: "acts of one or multiple inconvenient behaviors that harm the elders or distress them in a relationship with expectations of trust" (5). Violence against women, which is related closely to elderly abuse, is described as "in both public and private areas, an act which depends on gender that might/will give physical, sexual or psychological pain to women or threatening them with these kind of acts or forcing them or denying their independence arbitrarily" (6). We might encounter this in different forms like physical, emotional and economical violence.

Emotional violence is thought to be the most common violence against women and it is a type of gender apartheid. Correctly reporting the violence findings in these cases in terms of forensic medicine might prevent repetitive violence and providing social and psychiatric support to victims of violence might minimize the damage of trauma. We aim to remember that violence can come across clinicians in different formats in elderly patients by discussing domestic violence, violence to women and elderly abuse on a rare case.

\section{CASE:}

It is recorded that, an 83 years old female patient was brought to the emergency room of our hospital by 112 teams, her general situation was fine, she was conscious, oriented and cooperated, her vital findings were stabilized. In her physical examination performed by plastic surgery department; it was recorded that a total amputation that includes alar layers with columella and ranges from rinio on the tip of the nose to alar base was found, there were no malar asymmetry, bilateral frontal area, upper rims, lower rims and zygomatic arcs were natural with palpation, there were no step deformity, maxilla drawer test was negative, mandibular continuity was natural, temporomandibular joint examination was natural, sensory examination was natural, eye movements couldn't be examined due to periorbital oedema. In the tomography performed in our hospital, it was recorded that displaced fractures in nasal and ethmoid bones were determined and that it was suggested to hospitalize the patient in order to operate. The 
nose reconstruction was done with the person's forehead flap.

In our evaluation due to the consultation requested in terms of judicial reporting; the history of the incident was gathered from the patient's daughter due to lack of communication with the patient who has low hearing. She stated that, her parents argue frequently, they had fights before but injuries were mild, first her father beat her mother then tear off her mother's nose with a knife, she found out about the incident from her brothers, there were nobody near her parents while the incident was happening. Also she said that; ampute nose piece was not found in there. In the examination of the patient; her general situation was fine, she was conscious, her vital findings were stabilized, in her external examination; there was a $2 \times 1 \mathrm{~cm}^{2}$ purple colored ecchymose in midline of frontal area, $2 \times 2 \mathrm{~cm}^{2}$ dark-colored ecchymose in the left side of her forehead and oedema around right orbita and concomitant extensive ecchymose (fig 1).

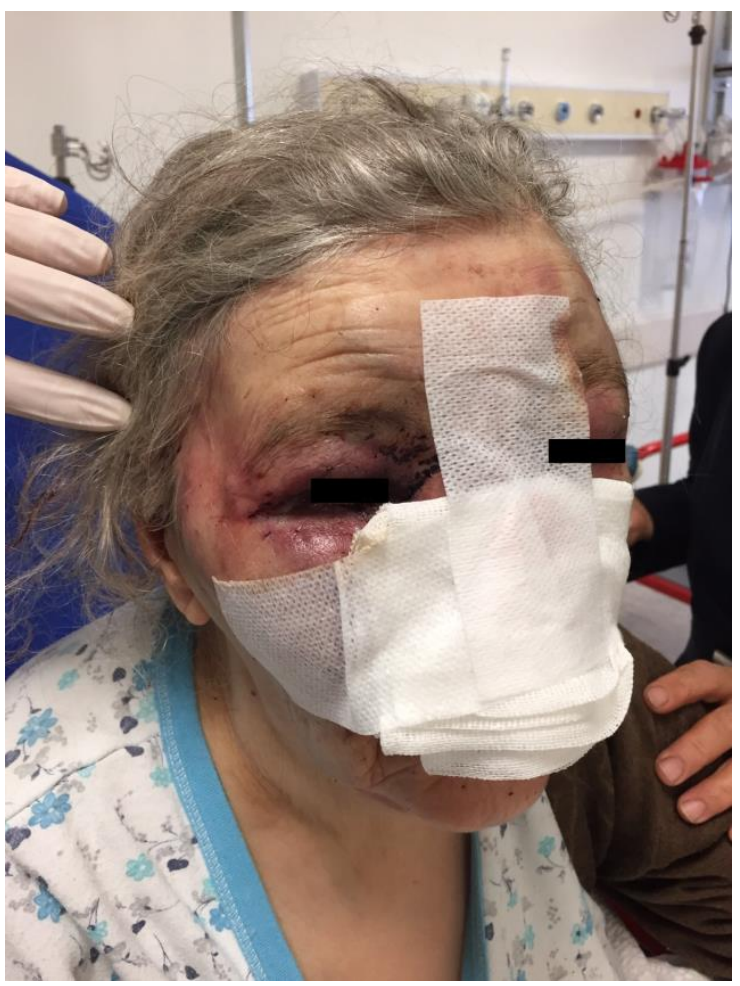

Figure 1-Ecchymoses of face
It was determined that nose was cut fullthickness starting from the nasal dorsum and including bilateral upper and lower cartilage tissue and amputated, the wound lips were smooth (fig 2),

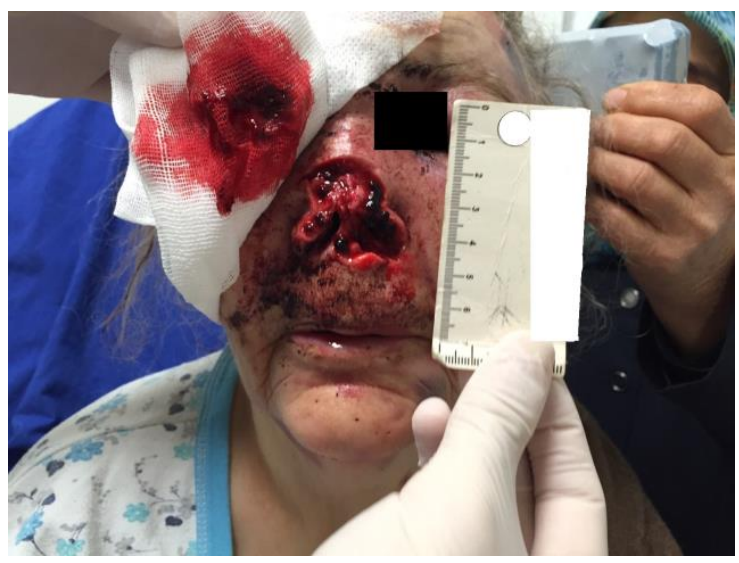

Figure 2- Total nose amputation

there was no other traumatic lesion except her face, motor, sensory and neurologic examination was natural, there were no other pathologies. In the evaluation of the patient file, it was determined that her hemoglobin was $11.5 \mathrm{~g} / \mathrm{dl}$ and haematocrit was $33.8 \%$ at the outer center, in the examination in our hospital, her hemoglobin was $11.7 \mathrm{~g} / \mathrm{dl}$ and her haematocrit was $34.5 \%$, patient had no severe blood loss.

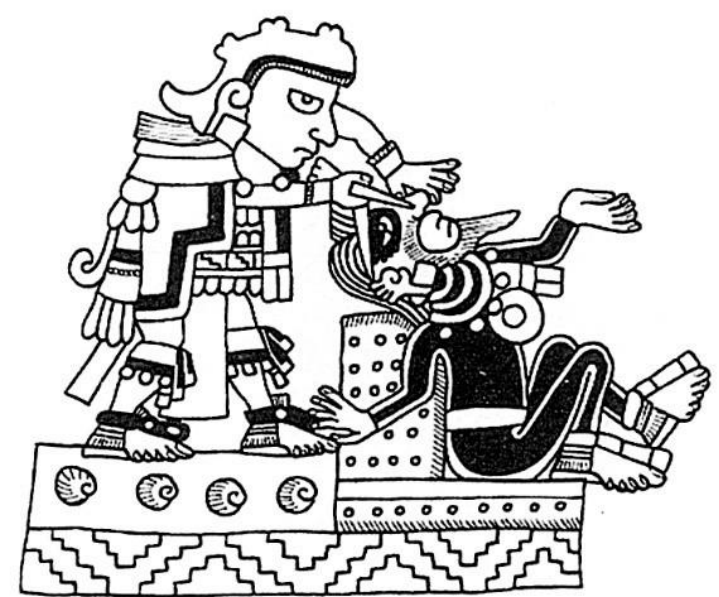

Figure 3 - Nose cutting penalty in history 


\section{DISCUSSION:}

Nose traumas usually occur in childhood and due to an accident. Rarely, animal bites might also cause injuries that include amputation of nose (7). In act of violence, there is also a tendency of attacking aesthetic organs and protruding organs due to their anatomic forms. While a boxing match in 1997, a boxer biting his opponent's ear and causing a subtotal amputation in an example for this. In history of humanity; we observe injuries of protruding parts of bodies (lips, tongue, chest, hands, genitals, nose, ears) due to judicial punishments (fig $3^{8}$ ). We encounter the amputation of particularly nasal pyramid as a law enforcement in ancient civilizations. There is evidence of performing this amputation in several civilizations as a punishment of adultery and thievery. Mummies that belong to ancient Egypt civilization that were examined also supports the other evidences. We can see that this punishment is also performed on some political dissidents. We can also see that women in $9^{\text {th }}$ century interestingly performed these injuries on themselves; it was stated that a priestess cut her own nose in order to look ugly and prevent the occupying soldiers to rape her (8). In today's world, in some societies, cutting of aesthetic organs such as nose is applied as a punishment method. In the recent past, a 12-year-old forced marriage bride, a famous magazine cover issue, is also the victim of this punishment system (9).

In literature, behaviors like self-mutilation and eating the ruptured limb parts are observed in patients with psychotic disorder (10). Nose as an important aesthetic factor of face, is possible to be attacked on purpose in order to take revenge or is jealousy cases. Similar to our case, we might encounter it as a type of elderly abuse and violence to women. Although nose replantation and reconstruction can be performed successfully with modern medical possibilities, erasing the marks of mental trauma is not easy at all $(11,12)$.

Population aged 60 and above which is $11.7 \%$ of the society in 2013 is predicted to pass beyond $21 \%$ and 2 billion in numbers in 2050 (13). Thus, elderly abuse is treated as an important public health problem recently. Elderly abuse has 5 types; physical, verbal or psychological, economical, sexual abuse and omission (14). It is shown that more than half of the elderly abuse, which is seen frequently in many societies but hard to reveal, is performed by partners. Risk factors for abuse are just like they are in youth; poor socioeconomic circumstances of partners, unemployment and drug abuse. In all age groups, legal acts must be done, educational programs and social society activities must be planned and creating awareness must be aimed in order to prevent violence and abuse.

Despite all the protective measures, in abuse cases, it is significant for patient to get medical and social support in early periods. Recording all kinds of abuse findings despite seeming simple and unimportant, reporting as a judicial case and preparing a correct judicial medical report by medical service providers has a big role on preventing the occurrence of bigger traumas. Reporting people with repetitive or severe trauma findings to ministry in order to provide social protection, providing rehabilitation and consultancy services might prevent abuses and minimize the trauma findings.

\section{REFERENCES:}

1. Yenilmez, M. Constructing Gender Equality through Fighting with Violence. Centre for Policy and Research on Turkey 2015 (4): 5; 64-79

2. Sancak B, Cumhur M. (Eds). Functional Anatomy; Head, neck and internal organs: 4th edition. ODTU: Ankara; 2008, pp 97-101 
3. Sagıroglu O.A. The Morphology of Nose, Turkiye Klinikleri Journal of E.N.T.-Special Topics 2009;2(2):1-10

4. W. Rodgers, T. Lloyd, L. Fourie, H. Nishikawa, D. Kuoraite, D. Dunaway, N. Bulstrode. Total reconstruction of the nose in settings where resourcesare limited, British Journal of Oral and Maxillofacial Surgery [Internet] Avaible from: http://dx.doi.org/10.1016/j.bjoms.2015.10.009 Accessed: 26.11.2015

5. WHO The Toronto Declaration on the Global Prevention of Elder Abuse, 2002 (http://www.who.int/ageing/projects/elder_abuse /alc_toronto_declaration_en.pdf Accessed: 26.11.2015)

6. United Nations, Declaration on the Elimination of Violence against Women (http://www.un.org/documents/ga/res/48/a48r10 4.htm Accessed: 26.11.2015)

7. Onur Gilleard, Laurent Smeets, Rohit Seth, Martin E. Jones. Successful delayed nose replantation following a dogbite: Arterial and venous microanastomsis using interpositional vein grafts, Journal of Plastic, Reconstructive \& Aesthetic Surgery 2014;67: 992-994

8. G. Sperati. Amputation of the nose throughout history, Acta Otorhınolaryngol Ital 2009;29: 44-50

9. Bibi

Aisha.

(https://en.wikipedia.org/wiki/Bibi_Aisha

Accessed: 19/01/2017)

10. Divya Sharma, Swapnil Agrawal, Devendra K Sharma, Devendra K Vijayvergia. Self-mutilation of nose in schizophrenia, Journal of Mental Health and Human Behaviour 2014;19(1):37-38

11. Sukwha Kim, Hoijoon Jeong, Tae Hyun Choi, Jun Sik Kim. Successful re-plantation of an amputated nasal segment by supermicrosurgery: A case report and review of the literature, Journal of Plastic, Reconstructive \& Aesthetic Surgery 2010;63;380-383

12. W. Rodgers, T. Lloyd, L. Fourie, $H$. Nishikawa, D. Kuoraite, D. Dunaway, N. Bulstrode. Total reconstruction of the nose in settings where resourcesare limited, British Journal of Oral and Maxillofacial Surgery Internet] Avaible from: http://dx.doi.org/10.1016/j.bjoms.2015.10.009

Accessed: 26.11.2015

13. World Population Ageing 2013. (http://www.un.org/esa/socdev/documents/agein g/Data/WorldPopulationAgeingReport2013.pdf Accessed: 26.11.2015)

14. Mark S. Lachs, Karl A. Pillemer. Elder Abuse, The New England Journal Of Medicine 2015;373:1947-56. 